\title{
KONSEP PENDIDIKAN ISLAM IBN THUFAIL
}

\author{
Muhammad Hanafi \\ STIT Palapa Nusantara \\ Hanafi@stitpn.ac.id
}

\begin{abstract}
In this postmodern era, an era of technological sophistication is the culmination, Islamic education always has its own appeal to continue to be studied more deeply and comprehensively. It is interesting to know, that Islamic education in particular is the brainchild of Islamic scientists, both Western and Eastern. One of them is Ibn Thufail, an Andalusian (Spanish) thinker and philosopher of Islam. His full name is Abu Baker Mubammad Ibn 'Abd al-Malik Ibn Mubammad Ibn Mubammad Ibn Thufail al-Qaisyi al-Andalusi. The concept of Ibn Thufail's education is related to the problem of sources and methods of acquiring knowledge. Related to Ibn Thufail's source of knowledge divides into two, namely buman sources (physics) and divine sources (metaphysics). Whereas the method of acquiring knowledge that was conceived was a method based on ratio, senses and intuition or soul.
\end{abstract}

Keywords: Ibn Thufail, source of knowledge, method of acquiring knowledge

\begin{abstract}
Abstrak : Di zaman postmodern ini, zaman yang kecanggihan teknologi merupakan puncaknya, pendidikan Islam senantiasa memiliki daya tarik tersendiri untuk terus dikaji secara lebih mendalam dan komprehensif. Menarik untuk diketahui, bahwa pendidikan Islam khususnya merupakan buah pikiran dari para ilmuwan Islam, baik Barat maupun Timur. Salah satunya Ibn Thufail, seorang pemikir sekaligus filsuf Islam berkebangsaan Andalusia (spanyol). Nama lengkapnya Abu Bakar Muhammad Ibn 'Abd al-Malik Ibn Muhammad Ibn Muhammad Ibn Thufail al-Qaisyi alAndalusi. Konsep pendidikan Ibn Thufail adalah menyangkut masalah sumber dan metode perolehan pengetahuan. Terkait dengan sumber pengetahuan Ibn Thufail membagi menjadi dua, yakni sumber insani (fisika) dan sumber ilahi (metafisika). Sedangkan metode perolehan pengetahuan yang digagasnya yaitu metode yang berdasar pada rasio, indra dan intuisi atau jiwa.
\end{abstract}

Kata kunci: Ibn Thufail, sumber pengetahuan, metode perolehan pengetahuan. 


\section{PENDAHULUAN}

Di zaman postmodern ini, zaman yang kecanggihan teknologi merupakan puncaknya, pendidikan Islam senantiasa memiliki daya tarik tersendiri untuk terus dikaji secara lebih mendalam dan komprehensif, serta selalu hangat untuk dibicarakan. Terutama kalangan akademisi. Hal ini karena pendidikan Islam berperan untuk membina manusia secara utuh (kâffah) dan seimbang (tawẫun), baik dari segi aspek rohani maupun jasmani. ${ }^{1}$

Menarik untuk diketahui, bahwa pendidikan Islam khususnya merupakan buah pikiran dari para ilmuwan Islam, baik Barat maupun Timur. Tapi pada abad pertengahan Islam di Barat (Spanyol) lebih menjadi perhatian dunia ketika mampu mentransfer khazanah-khazanah Islam di Timur dan bahkan mengembangkannya. Filsuf-filsuf yang kerya-karya besarnya banyak dikaji dunia, lahir di kota ini. Salah satunya Ibn Thufail, seorang pemikir sekaligus filsuf Islam berkebangsaan Andalusia (spanyol). Ibn Thufail telah menyihir para cendikiawan dunia dengan karya monumentalnya, Hayy Ibn Yaqdzan, salah satu karya yang tersisa dalam sejarah pemikirannya. Risalah atau novel alegoris yang bertajuk filosofis-mistis, menyita banyak perhatian dan namanya sangat populer baik di kalangan para pemikir muslim maupun nonmuslim.

\section{PEMBAHASAN}

\section{A. Biografi Ibn Thufail}

1. Ibn Thufail dan Karya-Karyanya

Nama lengkap Ibn Thufail adalah Abu Bakar Muhammad Ibn 'Abd alMalik Ibn Muhammad Ibn Muhammad Ibn Thufail al-Qaisyi al-Andalusi. Dia memiliki gelar al-Andalusi dan al-Qurtbubi. Di Barat Ibn Thufail dikenal dengan Abubacer. Ibn Thufail lahir di kota Wadi Ash (Guadix) tahun 508 H/1110 M, sebuah kota yang subur dekat Granada. Sebagai seorang keturunan suku Qaisy, suku Arab terkemuka, ia dengan mudah mendapatkan fasilitas belajar, apalagi kecintaannya kepada buku-buku dan ilmu pengetahuan. Hal ini mengutarakannya menjadi seorang ilmuwan dalam banyak bidang meliputi kedokteran, kesusastraan,

1 Heri Gunawan, Pendidikan Islam Kajian Teoretis dan pemikiran tokoh, (Bandung: PT Remaja Rosdakarya, 2014), hlm. iii. 
matematika, dan filsafat. Kedokteran dan filsafat dipelajarinya di Sevilla dan Cordova. ${ }^{2}$ Tidak banyak tulisan yang mengungkap masa kecil dan remajanya, termasuk perjalanan intelektualnya. Sebagian sumber menyebutkan bahwa Ibn Thufail berguru kepada filsuf Ibn Bajjah (w. $533 \mathrm{H}$ ). akan tetapi informasi ini masih perlu diteliti lebih lanjut. Sebab, seperti yang dikatakannya sendiri di dalam pendahuluan risalahnya, bahwa Ibn Thufail belum pernah bertemu dengan Ibn Bajjah secara face to face, meski ia sangat mengagumi dan mengakui kedalaman pengetahuan serta pemikirannya. ${ }^{3}$

Ibn Thufail memulai kariernya sebagai dokter pemerintah di Granada dan menjadi dokter di Sevilla dan Cordova. Dengan popularitas kariernya sebagai dokter di provinsi Granada, Ibn Thufail kemudian diangkat menjadi sekretaris gubenur di provinsi tersebut. Kemudian pada tahun 549 H/1154 M dia dipindah ke istana Dinasti Muwahiddun di Afrika Utara dan diangkat sebagai sekretaris gubernur Sabitab (Ceuta) dan Tanjah (Tangier), ${ }^{4}$ pernah juga ia diangkat petugas rahasia pangeran Abu Sa'ad ibn Abd al-Mu'min. ${ }^{5}$ Putra Abd al-Mu'min penguasa Dinasti Muwahiddun Spanyol pertama yang merebut Maroko pada tahun 542 H/1147 M. Akhirnya, ia menduduki jabatan dokter tinggi dan menjadi Qadhi di pengadilan serta Wazir. Selain itu, beliau juga mengabdikan diri dalam bidang pendidikan, pengadilan, dan penulisan. ${ }^{6}$

Nama Ibn Thufail kian mengharum ketika Abu Ya'kub Yusuf al-Manshur menjabat sebagai khalifah $(558 \mathrm{H})$. Pada saat itu, Ibn Thufail diangkat sebagai tabib (dokter) istana sekaligus menteri pada pemerintahan Dinasti Muwahhidun. Hanya saja, pada tahun 578 H/1183 M., Ibn Thufail mengundurkan diri dari istana, dan kedudukannya digantikan oleh Ibn Rusyd. Ibn Thufail meninggal dunia pada 581 H/1186 M., di Marakisy Maroko, dan dimakamkan di sana.

Kedekatan Ibn Thufail dengan penguasa Dinasti Muwahhidun, khususnya khalifah al-Manshur, yang dikenal memiliki minat yang besar terhadap ilmu

2 Abu Muhammad Iqbal, Pemikiran Pendidikan Islam Gagasan-Gagasan Besar Para Ilmuan Muslim, (Yogyakarta: Pustaka Pelajar, 2015), hlm. 175

${ }^{3}$ M. Hadi Masruri, Ibn Thufail: Jalan Pencerahan Mencari Tuban, (Yogyakarta: LKiS Yogyakarta, 2005), hlm. 34.

${ }^{4}$ Abu Muhammad Iqbal,Pemikiran Pendidikan Islam,hlm.175

${ }^{5}$ M. Hadi Masruri, Ibn Thufail, hlm. 34

${ }^{6} \mathrm{Abu}$ Muhamad Iqbal, Pemikiran Pendidikan Islam, hlm. 175 
pengetahuan, membawa angin segar bagi dunia pemikiran filsafat. Pada saat masih menjabat menteri, Ibn Thufail mempromosikan Ibn Rusyd kepada khalifah alManshur dan merekomendasikannya untuk memberikan anotasi (syarb) terhadap pemikiran filsafat Aristoteles, dan pada akhirnya, Ibn Rusyd berhasil menghantarkan filsafat ke jenjang paling tinggi dalam sejarah pemikiran Islam. ${ }^{7}$

Ibn Thufail sebenarnya mempunyai beragam karya, baik dalam bidang filsafat maupun yang lainnya (fisika dan sastra). Dari sejumlah karya yang dinisbatkan kepadanya, di antaranya: Risalah fi asrar al-Hikmah al-Masyriqiyyah (Hayy Ibn Yaqdzan); Rasa'il fi an-Nafs, fi Biqa' al-Maskunah wa al-Ghair al-maskunah. Selain itu, dia juga memiliki beberapa buku tentang kedokteran, serta risalah yang berisi kumpulan surat-menyurat yang beliau lakukan dengan Ibn Rusyd dalam berbagai persoalan filsafat. Ibn Rusyd menyatakan bahwa Ibn Thufail mempunyai teoriteori yang cemerlang dalam ilmu falak, diperkuat dengan pernyataan Leinn E. Goodman, bahwa Ibn Thufail ahli astronomi yang kemudian teori-teorinya dilanjutkan oleh temannya yaitu al-Bitruji. Akan tetapi, semua karya Ibn Thufail itu tidak ada yang tersisa, kecuali risalah Hayy ibn Yaqdzan.Tetapi menurut Ibn Khathib ada dua buku tentang kedokteran yang dapat dikatakan merupakan karya Ibn Thufail, setidaknya ditulis oleh dua orang muridnya yang dipersembahkan kepada Ibn Thufail, yaitu karya al-Bitruji berjudul Kitab al-Hai'ah, dan karya Ibn Ruysd berjudul Fi al-Buqa' al-maskunah wa al-Ghair al-Maskunah.

Namun menurut Lenn E. Goodman, Ibn Thufail bersama Ibn Rusyd telah menulis sebuah risalah ilmu kedokteran yang akhirnya disempurnakan oleh Ibn Rusyd, hingga Ibn Rusyd terkenal sebagai Averroes yang mempunyai karya monumental dalam bidang kedokteran. Sehingga pada saat itu Ibn Thufail dianggap sebagai figur revolusioner di Andalus. ${ }^{8}$

2. Sekilas tentang novel Hayy Ibn Yaqdzan

Risalah Hayy ibn Yaqdzan merupakan kisah yang memuat berbagai aspek: sastra, filsafat, tasawuf, pendidikan, dan sistem pengetahuan (epistemologi). Karena cakupannya yang luas dan isinya juga sangat menarik maka risalah Hayy ibn Yaqdzan diakui oleh banyak kalangan sebagai kisah filosofi terbaik dalam sejarah

7 M. Hadi Masruri, Ibn Thufail, hlm. 35.

${ }^{8}$ Abu Muhammad Iqbal,Pemikiran Pendidikan Islam, hlm. 176. 
filsafat Arab Islam. Kisah Hayy ibn Yaqdzan menggambarkan seorang anak manusia yang mampu hidup tanpa adanya unsur eksternal, seperti masyarakat, bahasa, budaya, agama, maupun dinamika sosial lainnya. Dalam kesendiriannya itu, seorang anak manusia yang hanya memanfaatkan sumber-sumber alam dan dengan kekuatan akal murninya, ternyata mampu mencapai pengetahuan sejati tentang alam atas, yakni tentang kebenaran Tuhan dan kekekalan jiwa. Kisah Hayy ibn Yaqdzan juga merupakan gambaran tentang fase-fase perkembangan akal murni, dari alam materi atau alam bawah ('alam al-adna) hingga tahapan tertinggi di dalam filsafat, yaitu alam merafisika (ma wara'a ath-thabi'ah). ${ }^{9}$

Kisah Hayy ibn Yaqdzan merefleksikan pemikiran filsafat Ibn Thufail. Dengan karya itu, ia berupaya menyelaraskan pemikiran rasional paripatetik Aristoteles dengan pemikiran iluminasi Neo-Platonisme. Jadi hal itu, tidak seperti yang dituduhkan Bkhtiar Husein Siddiqi, bahwa penyelarasan itu lebih merupakan usaha mencari kompromi antara pemikiran filsafat Ibn Bajjah dengan pemikiran mistis al-Ghazali, yakni upaya mencari jalan tengah antara filsafat rasionalis murni dengan pemikiran mistis. Akan tetapi lebih merupakan upaya harmonisasi antara pemikiran filsafat rasionalis paripatetik Aristoteles dan pemikiran iluminasi NeoPlatonik, yang dikembangkan oleh Ibnu Sina melalui filsafat Timurnya. Karena itu, pemikirian Ibn Thufail seperti halnya pemikiran Suhrawardi, lebih merupakan counter terhadap ajaran paripatetik Ibn Sina. Hal ini seperti dikatakan sendiri oleh Ibn Thufail dalam muqaddimah risalahnya itu, bahwa kisah Hayy ibn Yaqdzan merupakan uraian tentang rahasia-rahasia filsafat Timur yang dikembangkan Ibn Sina. Selain itu, penulisan karya Hayy ibn Yaqdzan juga dilatarbelakangi oleh ketidakpuasan Ibn Thufail terhadap jalan yang selama ini ditempuh oleh para sufi, seperti yang ditempuh oleh al-Ghazali.

Hanya saja, ketidak puasan Ibn Thufail bukan terletak pada metode sufi yang mengesampingkan aspek rasionalitas, akan tetapi ia ingin menegaskan bahwa metode iluminasi lebih tinggi dan lebih valid dalam mencapai kebenaran sejati daripada metode yang selama ini ditempuh oleh para sufi, termasuk al-Ghazali. Hal ini, setidaknya dapat dilihat dari tokoh Hayy ibn Yaqdzan, yang telah sampai

\footnotetext{
${ }^{9}$ M. Hadi Masruri, Ibn Thufail, hlm. 36-37.
} 
pada maqam penyaksian (al-musyâhadab), sebagaimana yang dicapai oleh para sufi, Hayy tetep berkontemplasi untuk dapat mengembangkan maqam-nya sehingga sampai pada penyinaran cahaya (isyrâq) dari alam atas, yakni esensi al-Haqq, sehingga memperoleh pengetahuan sejati tentang segala yang ada. Oleh karenanya banyak kalangan yang menilai bahwa kisah Hayy ibn Yaqdzan merupakan medium yang dipakai oleh pengarangnya untuk mempertemukan dua kosmos kebenaran, yaitu kebenaran realitas alam (filsafat) dan kebenaran wahyu (agama).

Risalah Hayy ibn Yaqdzan karya Ibn Thufail ini, sebenarnya bukanlah karya pertama. Ibn Sina misalnya, jauh sebelum Ibn Thufail, telah menulis cerita dengan judul yang sama dan menggunakan symbol serta nama-nama tokoh yang sama pula, seperti Hayy, Asal atau Absal, dan Salaman, meskipun substansi dan tujuannya berlainan. Menurut Ahmad Amin kisah Hayy ibn Yaqdzan karya Ibn Sina ini, bertujuan untuk menegaskan kekuatan akal dan keutamaannya dari segala yang dimiliki manusia, termasuk naluri dan instingnya, bahkan semua itu tunduk pada akal. Selain itu, Ibn Sina lewat karyanya itu, juga ingin menjelaskan bagaiman keterkaitan antara akal bawah dengan akal atas melalui akal sepuluh, yang merupakan sebab aktif dari segala yang ada, yakni Allah. Ibn Sina menggambarkan Absal sebagai al-'aql al-ną̧hari (akal teoritis) yang mencapai kesempurnaan dengan jalan al-irfani, dan Salaman sebagai al-nafs al-nathiqah (jiwa manusia). Sedangkan risalah Hayy ibn Yaqdzan karya Ibn Thufail meskipun bercerita tentang akal, namun ia lebih merupakan penegasan bahwa manusia dengan kekuatan akal yang dimilikinya mampu mencapai pengetahuan sejati tentang Tuhan dan juga tentang hakikat yang ada, yakni melalui pengamatan indrawi, penalaran rasional dan pengetahuan intuitif..$^{10}$ Selain itu, Ibn Thufail juga ingin menegaskan bahwa jalan menuju pengetahuan sejati tidak hanya bisa dicapai melalui rasio, akan tetapi juga bisa diperoleh melalui intuisi. Oleh karena itu, tokoh Hayy ibn Yaqdzan di dalam risalah Ibn Sina merupakan personafikasi dari akal, sedangkan di dalam kisah Ibn Thufail juga ingin melambangkan sosok manusia yang senantiasa hidup dengan mengoptimalkan akal dan intuisinya secara bersamaan.

${ }^{10}$ Abu Muhammad Iqbal, Pemikiran Pendidikan Islam, hlm.183-184 
Dari deskripsi di atas, menjadi sangat mungkin adanya pengaruh Ibn Sina terhadap pemikiran filsafat Ibn Thufail. Hal tersebut sesuai dengan teori "kesinambungan dan perubahan" -nya Jhon Voll, meskipun risalah Ibn Thufail memiliki substansi dan symbol yang berbeda.Terlebih lagi, Ibn Thufail di awal kisahnya menyatakan secara tegas bahwa tujuan penulisan kisahnya adalah sebagai "penjelas atas rahasia-rahasia filsafat iluminasi versi Ibn Sina". 11

Kisah Hayy ibn Yaqdzan, yang oleh G. Sarton dinalai sebagai the mos original works of the Midle Ages, ternyata mempunyai pengaruh yang sangat besar di Eropa, baik dalam bidang sastra maupun pemikiran filsafat, apalagi setelah karya tersebut diterjemahkan ke dalam berbagai bahasa Eropa. Bahkan kisah Hayy ibn Yaqdzan karnya Ibn Thufail itu dianggap sebagai yang paling besar pengaruhnya setelah buku Alf Lailah wa Lailah.

Selain itu, ada satu kisah fiktif berbahasa Inggris yang dinilai oleh berbagai kalangan banyak dipengaruhi oleh kisah Hayy ibn Yaqdzan, yakni kisah Ronbinson Crusoe dalam The Life and Strange Surpising Adventure of Robonson Crusoe (1719) karya danil De Foe, meskipun dalam berbagai aspek keduanya memiliki berbagai perbedaan. ${ }^{12}$

\section{B. Konsep pendidikan Islam Ibn Thufail}

1. Sumber pengetahuan

Ibn Thufail adalah seorang filsuf muslim yang dalam hal berfikirnya terkenal dengan tokoh filsuf-iluminasi (al-failasuf ak-isyraqy) yaitu memadukan daya rasio dan daya intuisi manusia. Jika diperinci daya rasio adalah kemampuan manusia dalam memahami segala kebenaran secara logis, empiris, dan melalui uji pengetahuan diskursif. Sedangkan daya intuisi adalah kemampuan jiwa, perasaan, atau emosi manusia dalam memahami hakikat entitas segala kebenaran yang ada. Jadi sumber pengetahuan menurut Ibn Thufail, yaitu:

a. Sumber insani (Fisika). Yakni terdiri dari, (1). Rasio (akal) dan (2). Indera (pengalaman). Baik itu indera mata (penglihatan), telinga (pendengaran), mulut (perasa), kulit (peraba), dan hidung (penciuman).

${ }^{11}$ M. Hadi Masruri, Ibn Thufail, hlm. 41.

${ }^{12}$ Ibid, hlm.43-44 
b. Sumber Ilahi (metafisika). (1). Intuisi (ilham) yaitu sumber pengetahuan yang diperoleh Hayy dengan indera keenamnya, melalui refleksi yang dalam dan olah spiritual yang tinggi. Sehingga Hayy pada keyakinan adanya jiwa, yang dalam pemikiran Ibn Thufail dipandang jiwa sebagai salah satu titik sentral karena melalui jiwanya manusia mampu mengetahui yang wajib ada Tuhan. (2). Wahyu yaitu pengetahuan yang yang berasal dari Al-Qur'an dan al-Sunnah, ini dikisahkan oleh Ibn Thufail dengan pertemuan Hayy dan Asal ternyata serupa pengetahuan yang diperoleh Hayy dan Asal yang mempelajari tasawuf dari teks wahyu. Ibn Thufail meyakini kebenaran wahyu dengan pemaknaan yang lebih mandalam, tidak terjebak pada teks wahyu. ${ }^{13}$

2. Metode perolehan pengetahuan

Kisah Hayy ibn Yaqdzan oleh banyak kalangan dipandang sebagai gambaran tentang perkembangan pengetahuan manusia (tathawwuru al-ma'rifah al-insâniyyah), dan hal itu nampak dalam tokoh Hayy yang hidup menyendiri di pulau terasing, bahkan terasing dari keluarga, masyarakat, budaya, agama, maupun dinamika sosial lainnya, mampu tumbuh dan berkembang sebagai filosof yang bukan saja ahli dalam pengetahuan empiris, melainkan juga sebagai teosofi (al-muta'allib) yang sampai pada kebenaran Tuhan, yang disebutnya sebagai pengetahuan sejati (al-haqầiq). ${ }^{14}$

Ada tiga metode perolehan pengetahuan menurut Ibn Thufail dalam karya monumentalnya Hayy ibn Yaqdzan sebagai berikut:

a. Dengan metode yang berdasar pada rasio:

1. Komparasi, analogi dan deduksi ketika Hayy membadah jasad ibunya sang rusa, serta penelitiannya pada seluruh benda yang ada di alam materi, sehingga dia berhasil mengetahui sifat dan tabiat yang kemudian diketahuinya sebagai hukum alam dan hukum kausalitas, yang membawanya pada kesimpulan bahwa segala yang ada itu sendiri terdiri dari empat unsur pokok: tanah, air, udara, dan api. Bahkan lebih dari itu Hayy berhasil mengungkap esensi seluruh benda-benda yang ada di alam

${ }^{13}$ Abu Muhammad Iqbal, Pemikiran Pendidikan Islam, hlm.186.

${ }^{14}$ Tim Dosen Fakultas Tarbiyah UIN Maulana Malik Ibrahim Malang, Pendidikan Islam Dari Paradigma Klasik Hingga Kontemporer, (Malang: UIN-Malang Press, 2009), hlm.,205 
bawah ini, yang menurutnya terdiri dari materi asal (al-hayula) dan bentuk (al-shurah).

2. Eksperimen ketika Hayy berhasil menemukan dan membuat api serta fungsinya secara detail. Berdasarkan pengalamannya dan pengetahuannya justru menjadikan Hayy terampil berburu, bahkan terampil menunggangi kuda yang telah dijinakkannya untuk dapat mengimbangi larinya binatang buruan.

b. Dengan metode yang berdasar pada indera:

1. Pengamatan, observasi dan penelitianyang digunakan Hayy secara bersama-sama untuk mengamati fenomena alam sekitarnya, dari segala benda, bebatuan, juga tumbuh-tumbuhan, berikut karakter masingmasing. ${ }^{15}$ Demikian juga di dalam melihat tabiat semua binatang, baik yang buas maupun yang jinak, terutama ibunya sang rusa (al-z̧habyah), serta segala yang ada di alam materiini. ${ }^{16}$

Daya keingin tahuan (curinosity) Hayy sedemikian kuat untuk mengamati, mengobservasi dan meneliti alam semesta, sehingga tatkala ibunya sang rusa yang telah memeliharanya mati, Hayy belum mengerti mengapa sang rusa secara mendadak tidak bergerak. Hay pun melakukan percobaan terhadap binatang lain, dia pun mengetahui sebab kematiannya, yakni tidak berfungsinya jantung. Hal inilah yang membawanya di kemudian hari pada kesimpulan adanya jiwa (al-nafs).

2. Peniruan yaitu cara yang dilakukannya sejak Hayy masih kecil terhadap berbagai perilaku binatang dan benda-benda di sekitarnya, sehingga diperoleh kekuatan dan ketajaman indera serta memiliki kekuatan nalar yang tinggi, seperti halnya bagaimana dia menguburkan jasad ibunya seperti yang diceritakan dalam kitab suci tentang burung gagak.

3. Penyerupaan kepada benda-benda empiric yaitu: (a). Amaliah menyerupai materi alam bawah (dunia); (b). Amaliah menyerupai materi alam atas (luar angkasa); (c). Amaliah imateri (abstrak) Yang Maha Agung. Untuk itu

${ }^{15} \mathrm{Abu}$ Muhammad Iqbal,Pemikiran Pendidikan Islam, hlm. 187.

${ }^{16}$ Tim Dosen Fakultas Tarbiyah UIN Maulana Malik Ibrahim Malang, Pendidikan Islam, hlm. 
Hayy ibn Yaqdzan melakukan tahapan-tahapan olah spiritual yang dikenal sebagai tiga tahapan penyucian jiwa (taækizyyah al-nafs) melalui penyerupaan terhadap siklus gerakan alam. Pertama, penyerupaan terhadap perilaku binatang, yang hanya bertujuan memenuhi kebutuhan jasmani, penyerupaan ini tidak akan menghantarkan seseorang ke derajat almusyahadah. Tahap kedua, penyerupaan terhadap perilaku benda-benda angkasa yang melambangkan sifat-sifat yang tinggi dan terpuji serta mempunyai siklus yang teratur. Hal lebih memungkinkan untuk menerima persepsi spiritual dari Tuhan, yaitu senantiasa menjaga kebersihan fisik, menjaga kedisiplinan diri dan keseimbangan dengan lingkungannya, serta menjauhi perilaku yang dapat menyebabkan kerusakan. Peniruan ini dapat menghantarkannya kepada derajat al-musyahadah, meskipun masih diliputi noda. Dan tahap yang ketiga, penyerupaan terhadap sifat-sifat Tuhan, yang imateri, yang arif, yang bijak da semua sifat kemahaan Tuhan. Penyerupaan yang ketiga inilah yang menurutnya dapat mencapai al-musyahadah yang sebenarnya dan tenggelam secara total pada yang al-Haqq.

c. Dengan metode berdasarkan pada intuisi atau jiwa:

1. Refleksi dan penyerupaan amaliah imateri berdasarkan pada daya jiwa manusia untuk bisa memaknai hakekat (esensi) segala yang ada dengan kearifan (moral tertinggi) yang terdapat pada ajaran-ajaran agama.

2. Metode penemuan (al-iktisyaf) yang digunakan Hayy untuk mengetahui rahasia yang terkandung dalam benda, misalnya Hayy membedah jasad rusa yang telah mati sehingga mengetahui secara detail seluruh bagian anggota tubuhnya, sekaligus fungsi dan kegunaannya masing-masing. Bahkan melalui penalaran dan kekuatan rasionya, Hayy berhasil menyingkap rahasia yang tersembunyi di balik jasad yang hidup, yakni adanya daya yang di luar jasadnya yang materi disebutnya sebagai ruh hewani yang merupakan penggerak bagi kehidupannya.

3. Terakhir metode penyerupaan, metode ini digunakan Hayy di dalam mencapai derajat tertinggi, yakni puncak kebahagiaan dalam ekstase total (al-fana al-tâmm), yang memungkinkannya melihat esensi Tuhan. Manusia tidak akan mencapai derajat tertinggi ini, kecuali senantiasa memikirkan 
dzat-Nya, serta membebaskan diri dari segala pikiran tentang yang bersifat inderawi. ${ }^{17}$

Proses pembelajaran yang di lakukan Hayy secara seimbang di dalam upaya memperoleh pengetahuan baik fisika maupun metafisika melalui tahapantahapan pendidikan yang dikenal sebagai: 1). Dari yang sederhana (al-Basith) kepada yang kompleks (al-Murakkab). 2). Pengetahuan Fisika ke pengetahuan metafisika. 3). Dari yang kongkrit (al-mabsus) ke yang abstrak (al-mujarrad). 4). Dari Tasawuf ke isyraqiyah (Illuminasi). 5). Dari yang Partikular (al-juz'i) kepada yang Universal (al-Kulli)

Lebih dari itu, tujuan pendidikan dalam perspektif Ibn Thufail adalah untuk mewujudkan manusia seutuhnya (insan kamil) dengan memadukan dua model pengetahuan sekaligus, yakni pengetahuan alam (pure reason) melalui penelitian diskursif (al-naz̧har al-aqli), dan pengetahuan agama, yang berdasarkan wahyu (revelation) melalui para nabi dan Rasul, sehingga tercapai sosok figus insan kamil sebagai filosof sufi yang illuminasionis, yang mampu menyeimbangkan kehidupan vertical dan kehidupan horizontal sekaligus. ${ }^{18}$

\section{KESIMPULAN}

Ibn Thufail merupakan filosof Islam berkebangsaan Andalusia, yang memiliki nama lengkap Abu Bakar Muhammad Ibn 'Abd al-Malik Ibn Muhammad Ibn Muhammad Ibn Thufail al-Qaisyi al-Andalusi, dan digelari dengan al-Andalusi dan alQurtubi, Dan kalau di Barat ia dikenal dengan Abu Bacer. Beberapa bidang keilmuan yang ia kuasai di antaranya kedokteran, kesusastraan, matematika, dan filsafat. Ibnu Thufail juga memiliki beberapa karya, yakni Risalah fi asrar al-Hikmah al-Masyriqiyyah (Hayy Ibn Yaqdzan); Rasa'il fi an-Nafs, fi Biqa' al-Maskunah wa al-Ghair al-maskuna.dan novel Hayy ibn Yaqdzan yang peling monumental.

Konsep pendidikan Ibn Thufail adalah menyangkut masalah sumber dan metode perolehan pengetahuan.Terkait dengan sumber pengetahuan Ibn Thufail membagi menjadi dua, yakni sumber insani (fisika) dan sumber ilahi (metafisika).

\footnotetext{
${ }^{17} \mathrm{Abu}$ Muhammad Iqbal, Pemikiran Pendidikan Islam, hlm.187-188.

${ }^{18}$ Tim Dosen Fakultas Tarbiyah UIN Maulana Malik Ibrahim Malang, Pendidikan Islam, hlm.
} 212-213. 
Sumber insani mencakup di dalamnya rasio (akal) dan indera (pengalaman). Sumber ilahi juga mencakup dua komponen, yakni intuisi (ilham) dan wahyu (Al-Quran dan Al-Sunnah). Sedangkan metode yang digagas oleh Ibnu Thufail adalah sebagai berikut.

1. Metode yang berdasar pada rasio, yang di dalamnya ada tindakan komparasi dan eksperimen.

2. Metode yang berdasar pada indera, yang di dalamnya ada tindakan pengamatan, peniruan, dan penyerupaan.

3. Metode berdasarkan pada intuisi atau jiwa, yakni ada di dalamnya tindakan refleksi dan penyerupaan amaliah imateri, penemuan (al-iktisyâf), dan penyerupaan yang digunakan untuk mencapai derajat tertinggi, yakni puncak kebahagiaan dalam ekstase total (al-fana al-tamm), yang memungkinkannya melihat esensi Tuhan.

\section{DAFTAR FUSTAKA}

Gunawan, Heri, Pendidikan Islam Kajian Teoretis dan pemikiran tokoh, (Bandung: PT Remaja Rosdakarya, 2014)

Iqbal, Abu Muhammad, Pemikiran Pendidikan Islam Gagasan-Gagasan Besar Para Ilmuan Muslim, (Yogyakarta: Pustaka Pelajar, 2015)

Masruri, M. Hadi, Ibn Thufail: Jalan Pencerahan Mencari Tuban, (Yogyakarta: LKiS Yogyakarta, 2005)

Tim Dosen Fakultas Tarbiyah UIN Maulana Malik Ibrahim Malang, Pendidikan Islam Dari Paradigma Klasik Hingga Kontemporer, (Malang: UIN-Malang Press, 2009) 